\title{
Employment in agriculture, migration, bilateral aids, economic growth and remittance: Evidence from the Gambia
}

\section{Ebrima K. Ceesay}

Department of Economics, School of Business and Public Administration, University of the Gambia, Gambia

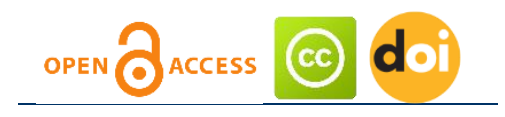

Article history:

Received: March 13, 2020

1st Revision: March 29,

2020

Accepted: April 14, 2020

JEL classification:
F43
O40
Q56

DOI:

10.14254/jems.2020.5-1.5

\begin{abstract}
For economic growth in any country must accompanied with skilled migration, persona remittances received, bilateral aid and improve food security through adaptation method of agriculture. In this regards, this study used the important of employment in agriculture, migration, economic growth, bilateral/foreign aids and remittances. We use data from WDI from 1960 to 2017 using linear regression models. Depending on the which variable we choose as dependent variable, the results confirmed that migration and remittances have significant positive impact on employment in agriculture in the Gambia. The results found out that employment in agriculture seriously has negative and significant impacts on bilateral aids. This may be due to the fact that the foreign aids received for agriculture is diverted to other used that could have less important to the economy growth. The results further explained that migration and economic growth are insignificant optimistic impacts on total aids in the Gambia, while remittance and employment in agriculture are statistically significant positive impacts on the total aids in the Gambia.10\% increase in migration, increases foreign aid by $50.3 \%$. This results is confirmed by Berthélemy, Beuran, and Maurel (2009) using World Bank bilateral data on the Effect of total aid on migration-push affect, $10 \%$ increase in aid in general increases migration by $1.5 \%$. When we used breakpoint date of 1981 and 1994 the results are structural stable due to the coups in the Gambia in 1981 and 1994. In addition, remittance, migration and foreign aid have positive significant impacts on economic growth. Increases $10 \%$ of remittance, increase economic growth by $0.14 \%$. Only employment in agriculture has negative impacts on
\end{abstract}


economic growth. $10 \%$ increases in employment in agriculture, decrease economic growth by $0.04 \%$.The economy of the Gambia should use the foreign aid to improve agriculture production and productivity thereby increase economic growth through export and eat what we grow.

Keywords: economic development, economic growth, society, remittance, migration, employment in agriculture, sustainability.

\section{Introduction}

The population of the Gambia is almost 2 million inhabitants, and one of the smallest and smiling coast countries in West Africa. Thus, it is smallest but illegal and legal ways of migration shows a major part in the society of the Gambia. The 20 per cent of the country's GDP is from money send back home by these people according to research revealed.

The economy overview of agriculture sector in the Gambia. The government of the Gambia should invest more in agriculture, because approximately half of its population depends on agriculture for their survival and livelihood of development. The contribution of agriculture is not that big compare to other sectors at $1 / 3$ of the GDP of the Gambia. This may be because agriculture share of the GDP lead to lower rainfall, high temperature causes by frequency of drought and storm. Less than half of the arable land is cultivated in the Gambia and that make agriculture production and productivity lower. The Gambia produces mainly peanuts, rice, millet, sorghum, corn, sesame, cassava, palm kernel, cattle, sheep and goats (Sources: www.indexmundi.com). In the Gambia proposed budget for 2020, less than 2 percent was allocated to agriculture. This cannot do anything for adaptation and mitigation strategies for the existing and future development of agriculture. Just recently around December 4, 2019, the board carry youth, women and children was going through backway to Europe capsized in the Mauritania river, killed 58 and injured 80 Gambians'. This is the key motivation for this study on development intervention (proxy agricultural employment) and migration.

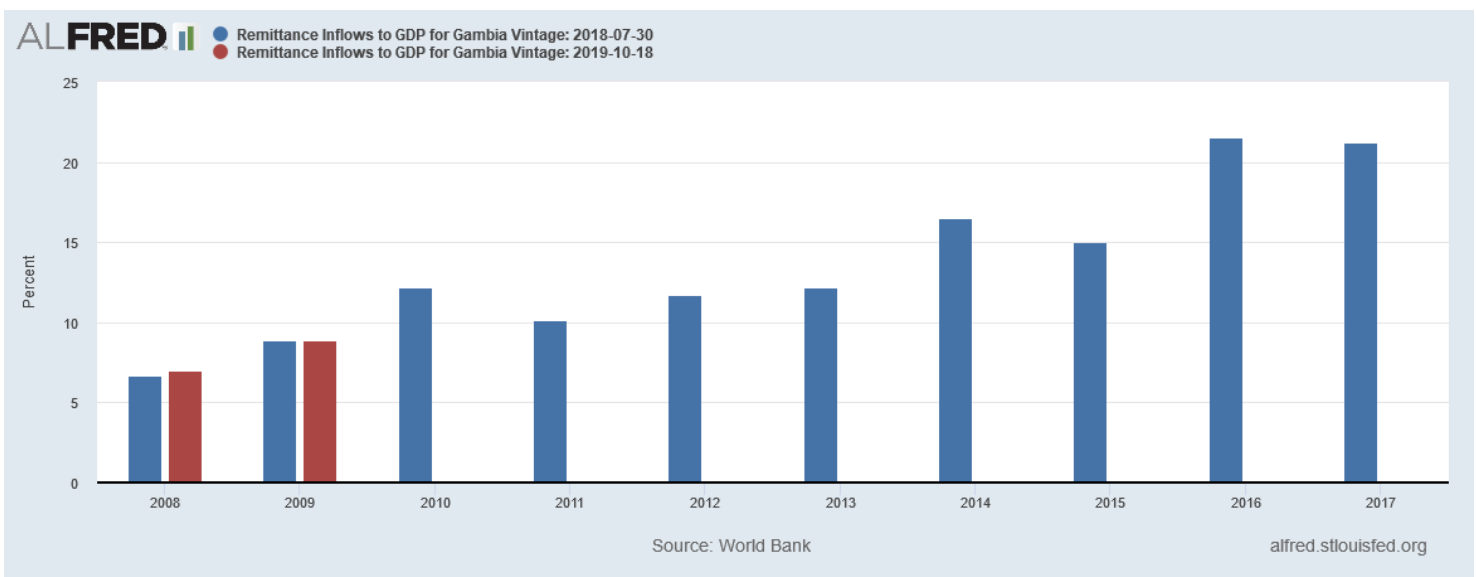

Source: Own Evaluation from IMF website

The rural-urban migration play a significant roles in the economy of the Gambia as the youthful population travelled to cities to find greener pastures. This make food insecurity and poverty to rise in the rural areas of the country in which only 16 percent have access to electricity supply compared to urban dwellers at 64 percent. Overall 47 per cent have access to electricity supply since independent. The poorest country in West African make the youth to have sociopsychological problems and that lead to risk journey to Europe. In current ages, the search for socioeconomic development particularly the youth has motivated numerous to start rough journey with the aim of getting into the Western world. At least 35,000 Gambians including male, female and children reached in Europe by irregular migration called back-way between 2014 and 2018 according IOM, Gambian's branch. The development intervention (proxy employment in agriculture) is developed by IOM the Gambia in order to facilitate, protection, reintegration and assist the migrant that were returned (IOM, 2018). The returnee benefits lots of facilities such as skills transfer, soft skills given (IOM,2018). This NGO'S work closely with the government of the Gambia to ensure the 
migrates are an important parts of the society and acts as human capital formation and that increases the long term economic growth and development in the Gambia. Those policy, programs and action can be implemented by the government of the Gambia to reduces and totally eradicate migration especially illegal migration to Europe. The migrations of youth should be great concern for the government of the Gambia as because most of them leave to other countries because of societal problems called socio-psychological problems of migration.

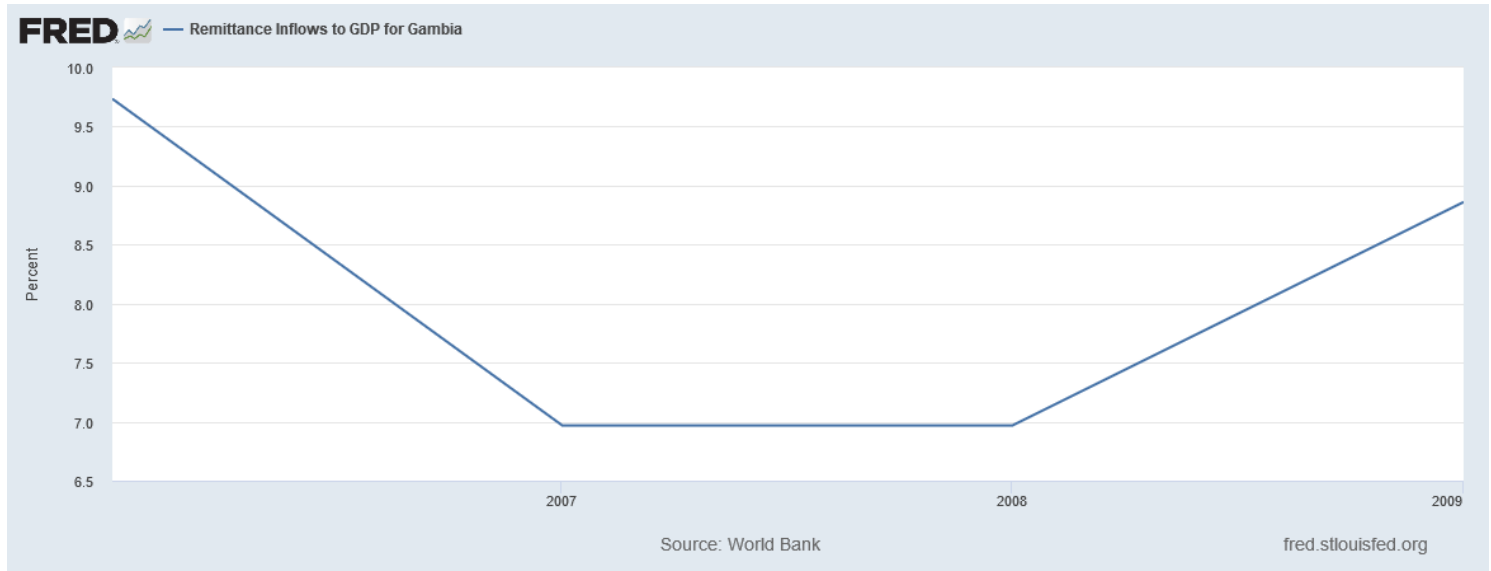

Source: Own Evaluation from IMF website

This is the key vital contributions in which peoples migrate to Europe. According to Ceesay et al., (2019b) personal remittance received have positive and significant impacts on economics in the Gambia by using Vector error correction model both in the short run dynamics and in the long run. Personal remittances received is a great source of foreign exchange earnings and also help in reducing the level of poverty in the developing countries (Ceesay et al., 2019b). According to International Organization for Migration (IOM the Gambia, 2017), personal remittances received was $\$ 215.7$ million. The Net Migration Rate was negative from 2015 to 2020 pegged at -1.217 migrants/1000 population (IOM the Gambia, 2017). As it can be seen in both the figures and the table above. In 2006 more migration occurred in the Gambia and the remittance as percentage of GDP was at 9.74 percent. From 2007 to 2008 constant growth of remittance occurred in the Gambia. From 2008 to 2009 remittance inflows begin to have an increasing or upward trend for the Gambia. Further, according to Ceesay, E. K., Belford, C., Fanneh, M., \& Drammeh, H. (2019a) export does not causes growth in the Gambia. Total imports caused growth and growth caused import in the Gambia (Ceesay, Belford, Fanneh \& Drammeh, 2019a).

Development intervention included and not limited to the following according to IOM; institutional capacities building, protection of vulnerable migrate either female or male, provision of rehabilitation support; raising awareness of the irregular migration, social transfers of remittance from outside, employment generation, insurance provisions, soft skills training, small and medium sizes enterprises support for the migrates(SME), new agricultural policy for development, basic local level service provision, migration management, and migration governance. it risk and danger to them as returnee and the society and surveying in-order to collect and analysis data on migration based on those who enter Europe, those who return back from Europe and remittance received by family members and others from Europe. This intervention play a vital role in reduces or eradicating migration through addressing the root causes of migration. Further, if we compared aids with migration interventions, according to most existing literatures, migration intervention is far better than giving loan or grant to the government. This is true because grant or loan with huge interests is mostly diverted to others investment that do not have direct impacts on migrates but the crowding out effects for corruption, mismanagement of funds and instability with high conflicts level that hindering the development of migrates and the societies as a whole. The questions are is development aid contribute to sustainable growth of the country(ies) economics? Another important question is development aid affects large variation in youth employment? According to study done by (Clements, 2018), there are small evidence that government aid from donors and others international organization helps to reduces the conflict. For Berthélemy, Beuran, and Maurel (2009) Using World Bank bilateral data to study the effect of total aid on migration-push factor and found out that 10 percent increase in aid, increase migration by 1.5 percent. More aid, more migration of the youth because of the diversification of the aid to unproductive policy intervention. The aid promote unskilled migration and does to contribute to the mitigation of migration. Scholarships as an aid, 10 percentage increases, increases skilled migration by 3 percent (Berthélemy, Beuran \& Maurel, 2009). In the macro studied by (Clements, 2018) sustainable economic development inclines 
to boost expatriation or migration in the lower undeveloped countries. Thus, in the micro studied done on social protection interventions by (Hagen-Zanker \& Himmelstein, 2013), revealed no agreement in the literature with development interventions having related with bidirectional effects. The review of the relevant literature was identified only a migration development intervention by (the New Zealand Recognized Seasonal Employment Programme) which have direct influences on firms or employers' migrants and countries of origin (Gibson \& McKenzie, 2013; Winters, 2016). The evidence base research in connection to migration interventions was found to be reliably fragile in most literatures. The lack of flexibility study to know the demand of skills or unskilled migrates, the labor market evaluation, gender sensitive policy for migration. This is very important in-order to gives unnecessary skills and training for displaced workers in the communities in which migration is the highest impacts factor. Impacts of migration interventions and development, as the studied of meta-analysis of energetic labour market programmes (ALMPs) in Europe (Butschek \& Walter, 2014) revealed that wage subsidies is directly positive impact on labour market outcomes for immigrants more than the training. This is established prove by additional paper by (Rinne, 2012) which reviewed immigration policies and procedures: programmes closely linked to the labour market were revealed to create moderately huge positive effects. Further, according to (McKenzie \& Yang, 2015) of evidence on policies to increase the developmental impacts of international migration shown that areas of policy success included bilateral migration agreements for countries whose workers have few other migration options, development of new investments or associated saving and remittance products, and initiatives to provide financial education to migrants and their families of how to have financial discipline and planning with credit facilities to put in good used for the development and long term positive impacts on the households consumption level and investment level. The literature with weak based highlights the limited empirical evidence available to guide the growing policy interest and efforts in relation to migration and development such as the work of Rinne (2012) and McKenzie \& Yang (2015). Therefore, the aim of the study is to links the agricultural employment, aids, personal remittance received of GDP and migration and added from the existing literature in which most of the research have not done anything about the multiple regression approaches especially for the Gambia to link development interventions(Agricultural employment), aids, economic growth, personal remittance and migration. This is new and oriented model for the Gambia to be able to predict the value of one variable over the value of another variable(s) called independent variable(s). The paper will also forecast the trends of the economic growth, migration, personal remittance received development intervention(agricultural employment) and aids in the Gambia for the couples of years to come. The research is limited to the data from secondary sources as WDI. This work is unique. That is the limitation of the study.

\section{Materials and Methods}

\subsection{Simple linear regression model}

Linear regression is a technique to quantify the relationship between the dependent variable and only one independent variable.

$$
y=\beta_{0}+\beta_{1} x
$$

In this equation $y$, is the dependent variable, is the variable on the vertical axis of the graph or the explained variable, while $\mathrm{x}$, represents the variable on the horizontal axis or the independent variable. The value $\beta_{0}$ (which can be negative, positive or zero) is called the intercept, while the value $\beta_{1}$ (which can be positive or negative) is called 'slope' or 'coefficient of regression' or rate of change. The question is how to calculate the values of $\beta_{0}$ and $\beta_{1}$. You will not be bothered with the details but in all statistical textbooks you will see that $\beta_{0}$ and $\beta_{1}$ can be calculated with the following equations:

$$
\beta_{1}=\frac{\sum\{(x-\bar{x})(y-\bar{y})\}}{\sum(x-\bar{x})^{2}} \text { and } \beta_{0}=\bar{y}-\beta_{1} \bar{x}
$$

\subsection{Multiple linear regression model}

This paper is based on multiple regression analysis in which two or more variables are modeling and analysis. The multiple regression analysis is to describe the relationship between one dependent variables called responsed variable and several independent variables called exogenous variables (Constantin, 2006). Lefter, 2004, identified that and at the same time the spreads in which some independent variables have on the dependent variable under study. Sometime it takes into account the forecasting or predicting the values of independent variables on the outcomes either positive or negative it will have on the dependent variable. The multiple regression models can be much more accurate than the uni-factorial regression model (Goschin \& Vatui, 2002).In our study, 
the dependent variable for the multiple regression analysis is development intervention (employment in agriculture ) and the independent variables are Net migration, net official aid received, economic growth, and Net official development assistance and official aid received. All of the variables were used for our analysis throughout the periods from 1969-2016. We first found out the data from WDI and we used the data to obtained our regression equation and calculated the standard error, the t-statistic, the p-value and the R-squared. These variables all measured the goodness of fit or accuracy of the estimates of the model especially the R-squared, which is called coefficient of determination in which is the proportion of how much the total variance is explained by the independent variables in the model. We also have others test like F- statistic, t-ratios and pvalues to test the hypothesis and indicated the rejection region in the model with degrees of freedom.

If $\mathrm{y}$ is a dependent variable and $\mathrm{x}_{1}, \ldots, \mathrm{x}_{\mathrm{k}}$ are independent variables, then the multiple regression model provides a prediction or forecasting of $\mathrm{y}$ given $\mathrm{x}_{\mathrm{i}}$ of the form

$$
y_{i}=b_{0}+b_{1} x_{1 i}+b_{2} x_{2 i}+\ldots \ldots+b_{p} x_{p i}+e_{i}
$$

Where the assumption on the error terms are exactly as in simple linear regression. In order to estimate the coefficients and se (standard error of the estimate), one follows a process very similar to that followed in the case of only one predictor value. The left hand size variable is the dependent variable and the right hand size variable is the independent variables. The paper used the multiple regression analysis to direct predict the values of development intervention (employment in agriculture) to migration in the Gambia.

\subsection{Empirical model}

Do aid/development interventions/personal remittances deter irregular migration specifically? This is linear regression between aid and net migration and between development intervention and net migration decision and between personal remittances received and net migration.

Does net migration affect total bilateral aid received in the Gambia?

$$
\operatorname{taid}_{\mathrm{it}}=\gamma_{0}+\mathrm{NM}_{\mathrm{it}} \gamma_{1}+\varepsilon_{\mathrm{it}}
$$

Does personal remittance received affect net migration?

$$
\mathrm{NM}_{\mathrm{it}}=\gamma_{0}+\mathrm{PR}_{\mathrm{it}} \gamma_{1}+\varepsilon_{\mathrm{it}}
$$

Do personal remittances received affect economic growth?

$$
\mathrm{EG}_{\mathrm{it}}=\gamma_{0}+\mathrm{PR}_{\mathrm{it}} \gamma_{1}+\varepsilon_{\mathrm{it}}
$$

Does net migration affect economic growth?

$$
\mathrm{EG}_{\mathrm{it}}=\gamma_{0}+\mathrm{NM}_{\mathrm{it}} \gamma_{1}+\varepsilon_{\mathrm{it}}
$$

Does net migration impacts on development intervention, when we considered employment in agriculture as a proxy for development intervention?

Does development affect aid?

$$
\mathrm{EADI}_{\mathrm{it}}=\gamma_{0}+\mathrm{NM}_{\mathrm{it}} \gamma_{1}+\varepsilon_{\mathrm{it}}
$$

Do aid affect economic growth?

$$
\text { taid }_{\text {it }}=\gamma_{0}+\text { EADI }_{i t} \gamma_{1}+\varepsilon_{\text {it }}
$$$$
\mathrm{EG}_{\mathrm{it}}=\gamma_{0}+\operatorname{taid}_{\mathrm{it}} \gamma_{1}+\varepsilon_{\mathrm{it}}
$$

Multiple linear regression models between development intervention (proxy agriculture employment), net migration, personal remittances, bilateral aids and economic growth are given below.

Does net migration, net official aid received, personal remittances received and economic growth affects development intervention (employment in agriculture)?

$$
\mathrm{EADI}_{\mathrm{it}}=\gamma_{0}+\mathrm{NM}_{\mathrm{it}} \gamma_{1}+\operatorname{taid}_{\mathrm{it}} \gamma_{2}+\mathrm{EG}_{\mathrm{it}} \gamma_{3}+\mathrm{PR}_{\mathrm{it}} \gamma_{4}+\varepsilon_{\mathrm{it}}
$$

Does aid affect personal remittances received, net migration, development intervention and economic growth?

$$
\text { taid }_{\text {it }}=\gamma_{0}+\mathrm{NM}_{\mathrm{it}} \gamma_{1}+\mathrm{EADI}_{\mathrm{it}} \gamma_{2}+\mathrm{EG}_{\mathrm{it}} \gamma_{4}+\mathrm{PR}_{\mathrm{it}} \gamma_{4}+\varepsilon_{\mathrm{it}}
$$

Does net migration affect personal remittances received, aids, development intervention and economic growth?

$$
\mathrm{NM}_{\mathrm{it}}=\gamma_{0}+\text { taid }_{\mathrm{it}} \gamma_{1}+\mathrm{EADI}_{\mathrm{it}} \gamma_{2}+\mathrm{EG}_{\mathrm{it}} \gamma_{4}+\mathrm{PR}_{\mathrm{it}} \gamma_{4}+\varepsilon_{\mathrm{it}}
$$

Do personal remittances received affect net migration, aids, development intervention and economic growth?

Where:

$$
\begin{aligned}
& \mathrm{PR}_{\mathrm{it}}=\gamma_{0}+\operatorname{taid}_{\mathrm{it}} \gamma_{1}+\mathrm{EADI}_{\mathrm{it}} \gamma_{2}+\mathrm{EG}_{\mathrm{it}} \gamma_{4}+\mathrm{NM}_{\mathrm{it}} \gamma_{4}+\varepsilon_{\mathrm{it}} \\
& \mathrm{EG}_{\mathrm{it}}=\gamma_{0}+\operatorname{taid}_{\mathrm{it}} \gamma_{1}+\mathrm{EADI}_{\mathrm{it}} \gamma_{2}+\mathrm{PR}_{\mathrm{it}} \gamma_{4}+\mathrm{NM}_{\mathrm{it}} \gamma_{4}+\varepsilon_{\mathrm{it}}
\end{aligned}
$$

EADI: Development Intervention (Proxy employment in agriculture)

NM: Net migration

EG: GDP growth 
taid: total aid

taid: (Net bilateral aid flows from DAC donors, United States+ Net bilateral aid flows from DAC donors, European Union institutions+ Net official development assistance and official aid received)

PR: Personal remittance received

\section{Data and descriptive statistics}

A brief descriptive of the data, the name of the variables, data sources and comment used in this study are presented in the table 1 and to cleaned the data for missing data, we applied interpolation to fill the missing values, because its advantages over the other methods is that, Linear interpolation is quick and easy to use, and may be adequate for well-resolved data comparing to Polynomial interpolation, Cubin Spline Interpolation. The periods 2018-2022 is used for forecasting purpose only. This mean we also want to know the forecasted economic growth, net migration, personal remittance, employment in agriculture and bilateral aid received in the Gambia for the upcoming years.

\section{Presentation of econometrics results and discussion}

For all the following tests, we choose 0.05 level of significance. The decision rule is: If the value of the probability is higher than the 0.05 level, then we do not reject the null hypothesis $\mathrm{H} 0$.If the value of the probability is smaller than the 0.05 level, then we reject the null hypothesis H0. To test the correlation, the test of hypothesis is as follows: H0: X and Y are not correlated and Ha: X and Y are correlated.

\section{Linear correlation coefficient}

In the table 3 below, the linear correlation coefficient of 0.6362 has a p-value of 0.0000 indicating that Development Intervention when we take employment in agriculture as a proxy and economic growth of the Gambia are positively correlated because $p=0.000<0.05$. Thus, the linear correlation coefficient of 0.057438 has a p-value of 0.6685 meaning that economic growth and net migration are not correlated in the Gambia, because the p-value $=0.6685>0.05$. For the linear correlation coefficient of the relationship between net migration and personal remittance received are positively correlated. Net migration increases, personal remittances received from outside rises at approximately 58 percent the study confirmed. Current Total aid from donors outside has positively correlated with net migration, personal remittances received, economic growth and even development intervention when we considered employment in agriculture as proxy, because there p-values' is less than 0.05 .

\section{Jarque Bera normality test}

The test of hypotheses is as follows: H0: X follows a normal law of parameters m and $\sigma$ and Ha: $\mathrm{X}$ does not follow a normal law of parameters $\mathrm{m}$ and $\sigma$. Note: $\mathrm{m}$ and $\sigma$ are respectively mean and standard deviation.

All the critical probabilities are less than the 0.05 level except for personal remittances received from outside : development intervention when we considered employment in agriculture as proxy, economic growth, net migration, total aid does not follow normal laws on the period going from 1972 to 2001,except PR which follow normal laws. Simple Linear regression from our methodology above:

i) Does net migration affects total aid in the Gambia?

In time 5 below, when we considered total aid as our endogenous variables, we obtain the evidence of negative relationship between net migration and total aid received in the Gambia. Even though the probability values is statistically significant at 5\%. 1\% increase in net migration in general decreases total aid received in the Gambia by approximately 9.2\%. From the existing point of view, Mauro Lanati and Rainer Thiele 2018, wrote on the impact of foreign aid on migration revisited, found out a negative correlation between the total aid a country obtains and emigration rates. This evidences was also confirmed by most important empirical study alongside these lines is Berthélemy, Beuran, and Maurel (2009), who study the connection between the total aid received in a country and migration for a large cross section of developing countries. In addition, they reflect a network effect through which bilateral aid may be linked with higher migration flows: more bilateral associates through the operation of aid projects rises the info on the donor country obtainable among potential migrants in the receiver country, that suggests lesser transaction costs for the migrants. Their cross-section assessments show that both bilateral aid and recipient's total aid have meaningfully positive influences on migrant stocks. Furthermore, Berthélemy, Beuran, and Maurel (2009) Using World Bank bilateral data Effect of total aid on migration-push affect/allowing migrants 
to afford the cost of migration-10\% increase in aid in general increases migration by $1.5 \%$-promotes unskilled migration. Bilateral aid-contact facilitation/attraction effect scholarships-10\% increase in bilateral aid increases migration by 3\%-promoted skilled migration (Berthélemy, Beuran \& Maurel, 2009).

\section{ii) Does personal remittances received affects net migration in the Gambia?}

From the results generated in table 6 below, personal remittances received from outside from 1960 to 2017 confirmed that personal remittances received has statistically significant negative impacts on net migration in the Gambia. 1\% increase in personal remittances received from outside lead to reduction in net migration in the Gambia by approximately $24.3 \%$.The more personal remittances received from outside, the more the reduction in migration in the Gambia. This is obviously a good finding, because as the more personal remittances received, will discourage youth for migrate or even taking illegal road thereby they use that money for investment into businesses, education attainment, households consumption, food security, poverty reduction, employment creations, agriculture sustainability, youth training etc. From the existing literatures point of views, For instance, a study by Lokshin et al. (2010) indicate that one fifth of the poverty reduction in Nepal that took place between 1995 and 2004 is due to labour migration and remittances. Equally in their part, Prabal and Ratha (2012) demonstrate that remittances in Sri Lanka have assisted migrant households move up the income- ranking. Komla Amega, 2018 wrote on remittance, education and health and confirmed that in sub-saharan Africa, remittances have significant positive impact on education. Research by Amakom and Iheoma (2014) on 18 Sub-Saharan countries using two-stage least square established that primary school enrollment and secondary school enrollment rises by $4.2 \%$ and $8.8 \%$, for every $10 \%$ increase in remittances.

Lu and Treiman (2007) in their part argued that in South Africa, children from remittance recipient households and those that are Blacks were $30 \%$ more likely to have some secondary education compared to non-migrating households without remittances. Remittance recipient households were also $73 \%$ likely to have

In Ghana, it was confirmed the probability a child enrolls in primary school rises by $13 \%$ if a household's position moves from a non-international remittance recipient household's to an international5 remittance recipient household's. Likewise, the likelihood of joining a secondary school increases by $54 \%$ for the same household status change to international remittances recipient. Households headed by females were also likely to invest remittances received into children's education than those headed by men (Gyimah-Brempong \& Asiedu, 2009; 2015).

In sub-Saharan Africa, Amakom and Iheoma (2014) using two stage least square estimation obtained $10 \%$ rise in remittances rise life expectancy at birth by $1.2 \%$ on average. This impact was larger than those created by public health expenditure per capita; which was $0.5 \%$ on average for every $10 \%$ increase in public health expenditure per capita.

\section{iii) Do personal remittances received affect economic growth?}

From table 7. Below, the results found out that personal remittances received from outside has significant positive impacts on economic growth in the Gambia. $10 \%$ increase in personal remittances from abroad, rises the economic growth in the Gambia by approximately $0.11 \%$. This result is confirmed with the finding of Ceesay et al, $2019^{\mathrm{b}}$ that personal remittance received have positive and significant impacts on economics in the Gambia by using Vector error correction model both in the short run dynamics and in the long run. Personal remittances received is a great source of foreign exchange earnings and also help in reducing the level of poverty in the developing countries (Ceesay et al, 2019b). Jemma Dridi, Tunc Gursoy, Hector Perez-Saiz and Mounir Bari, 2019 wrote on the impacts on remittances in economic activity in sub-Saharan African countries and confirmed in their finding that remittances increases economic activity with degree of linkages the remittances received across sectors e.g. such as financial intermediary sector. Thus, remittances improve the likelihoods of reduction in poverty, increases education enrolment, improve investment, decreases food in-security, improve health. The results confirmed that remittances benefits both individual's, entire country's and the continents' like in sub-Saharan Africa, Asia etc.

iv) Does net migration affect economic growth?

From table 8, in the Gambia, migration has positive but fairly small impact on economic growth. The results of the study confirmed that migration does have impacts on economic growth. If migration increases by $0 \%$, economic growth in the Gambia will reduces by $1.8 \%$.This tell you that migration have impact on economic growth of the Gambia. If no migration, Youth migration both skilled migrates and unskilled migrates send remittances back home and that remittances is used to do social function, households consumption expenditure-children school fees, health care for children, food, clothing and some used to build houses etc. All in turn can improve economic growth 
in the Gambia by long run non-economic measure such as quality of life, standard of living of the household's, education, health, agriculture improve, family businesses etc. decade. Over the past ten years, immigrants signified $47 \%$ of the rise in the workforce in the United States, and $70 \%$ in Europe (OECD, 2012). One of the study that looks at the impact of migration on economic growth for 22 OECD countries between 1986 and 2006 proves an optimistic but fairly small impact of the human capital brought by migrants on economic growth. The involvement of immigrants to human capital accumulation tends to counteract the impact of population increase on capital per worker, but the net effect is fairly small. An increase of $50 \%$ in net migration of the foreign-born makes less than one tenth of a percentage point difference in productivity growth (Boubtane \& Dumont, 2013).

\section{v) Do total bilateral aids affect economic growth?}

The results in the study from table 9 found out that bilateral aids received are slightly significant positive impact on economic of the Gambia. This impact is very small to influence the effect of bilateral aids contribution to the economic growth. This may due to the fact that aids fail to reach the poor in the Gambia. Though, foreign aids increase the economic growth in most of the poor countries if aids are the only sources of funding. If total bilateral aids received are utilized in good way, it can be a important sources of income to reduces poverty and improve economic development of the Gambia. In their parts, Sebastian Galiani, Stephen Knack, Lixin Colin Xu and Ben Zou, 2016 confirmed that $1 \%$ percent increase in the aid to gross net income ratio increases annual real per capita GDP growth by $0.031 \%$. Bilateral aids is not bad for the countries but the management of funds to have impacts to the beneficiaries is crucial factors that increases growth and development. Bilateral aid received is supposed to directly influence economic development of the beneficiary country, but sometimes this is not the case due to many factors such as corruption, mismanagement of funds, lack of impacts evaluation, accountability and transparency. A large number of studies to evaluate the impact of bilateral aid in promoting economic growth and development of recipient countries have been carried out. The results of these studies are different depending on the methods, country(ies) and even the time periods. For example, Hansen and Tap (2001), Karras (2006), Astreriou (2009), Minoiu and Reddy (2010) deliver evidence that bilateral aid have optimistic impact on growth.Adam and O'Connell (1999), Burke and Ahmadi-Esfahani (2006), and Carden (2009) find evidence for unimportant and even negative role of aid on economic growth. Burnside and Dollar (2000), Collier and Hoeffler (2004), Easterly et al.(2004) and Alfaro et al.(2004) provide evidence that positive role of aid on economic growth can be realized only when certain conditions such as good macroeconomic condition, political stability and less corruption exist. The successful of bilateral aids recipients country(ies) depending upon the country to have Voice and Accountability, Political Stability and Absence of Violence, Government Effectiveness, Regulatory Quality, Rule of Law, and Control of Corruption.

\section{vi) Does net migration affects employment in agriculture?}

As the results generated in table 10 below, migration is statistical insignificant positive impact on employment in agriculture. As peoples migrates, those left behind there will be scarcity of employment in agriculture and in- turn will negatively impacts on food security and economic growth. Not only that, but those left behind are mostly women, children, elderly and disable peoples and in that their contribution to agriculture, food security and nutrition will be minimal. In the likelihoods they can be affected by poverty and hunger, malnutrition and diseases, lack of education especially children etc. That is one sided of the story. Another sides of migrates remittances also help those left behind to have quality education, good health, food security, new agriculture technology etc..(see the link between migration and personal remittance received from outside).In the most of the literatures that links migration and employment in agriculture found out that food security and migration can be direct, due to food insecurity and fluctuations of income, the links between agriculture, food security and migration can be indirect(FAO IFAD IOM WFP. 2018). Agriculture and rural development can show a significant role in addressing the adverse drivers of migration and in concentrating on the social and economic situations of rural areas of origin and destination (FAO IFAD IOM WFP, 2018).

vii) Does development affect aid?

Although agriculture is significant contributors for the food security of most countries in Africa, particularly the poor countries, bilateral donors did not agree that as a high priority. Both volume and share of bilateral aid received reserved for agriculture in sub-Saharan Africa remained low, but constantly deteriorated. From table 11, the results found out that employment in agriculture seriously has negative and significant impacts on bilateral aids. If employment in agriculture increases bilateral aids reduces drastically. This may be due to the fact the aids received for agriculture is diverted to other used that could have less important to the economy growth. 


\section{Multiple linear regression model}

i) Does net migration, net official aid received, personal remittances received and economic growth affects development intervention (employment in agriculture)?

When we used multiple regression analysis, the results confirmed that migration and remittances have significant positive impact on employment in agriculture in the Gambia. The impacts is more larger for remittances than migration itself.10\% increase in remittance, increases the employment in agriculture by approximately $0.29 \%$ if others variables remained constant. Bilateral aids is fairly positive significant impacts on employment in agriculture, while economic growth have significant negative impact on employment in agriculture.10\% increases in economic growth, decreases employment in agriculture by $0.05 \%$. This is confirmed in the study done by Clemens, 2018 disbelief about the ability of development aid to effect large variations in youth employment. Previous studies have studied the role of foreign aid to agriculture in economic growth and poverty reduction with diverse results (Kaya, Kaya and Gunter, 2012, 2013; Mavrotas, 2003, 2003; Clemens et al., 2004). Certainly the relationship between foreign aid and economic growth remains a hot debate. Thus, there is rare studied done on the relationships between employment in agriculture, migration, personal remittance, bilateral aids and economic growth.(Kaya, Kaya and Gunter, 2012, 2013; Clemens et al., 2004).

ii) Standardized coefficients

The relative importance of determinants of the employment in agriculture from table12 above is evaluated by standardized coefficients. After having estimated the parameters by the OLS. The standardized coefficients associated with net migration, bilateral aids, economic growth and remittance variables are respectively $10.43949,4.9019,-6.518037$, and 10.29534 . Development intervention (proxy employment in agriculture) in the Gambia is more affected by net migration and personal remittances received and medium affected by bilateral aids received and less affected by economic growth. Does aid affect personal remittances received, net migration, development intervention and economic growth?

The results from table 14 explained that migration and economic growth are insignificant positive impacts on total aids in the Gambia, while remittance and employment in agriculture are statistically significant positive impacts on the total aids in the Gambia.10\% increase in migration, increases total aids by 50.3\%. This results is confirmed by Berthélemy, Beuran, and Maurel (2009) using World Bank bilateral data on the effect of total aid on migration-push affect/allowing migrants to afford the cost of migration-10\% increase in aid in general increases migration by $1.5 \%$-promotes unskilled migration. Bilateral aid-contact facilitation/attraction effect scholarships-10\% increase in bilateral aid increases migration by 3\%-promoted skilled migration. Aid supportive rural development had very small positive effects on the reduction of rural migration (Gamso \& Yuldashev, 2018).

Does net migration affect personal remittances received, aids, development intervention and economic growth?

Migration and remittances are inseparably entwined. While remittances would not happen if the senders had not migrated in the first place, migration is often inspired by the desire to improve the welfare of those left behind, mainly family members or friends by sending them money. Migration profiles such as destination and migrant characteristics are likely to influence remittance patterns. From table15 below, when we used net migration as the dependent variables the results found out that employment in agriculture and economic growth are positive significant effects on migration but remittances has significant negative impacts on migration.10\% increase in remittance, decreases migration by approximately 304\%.There is large volumes of migration from the Gambia especially those using the Mediterranean seas, how much does getting good jobs to send remittances back home. Unskilled migration reduces remittances as the studied confirmed, while skilled migration increases remittance. $10 \%$ increase in employment in agriculture, increases migration by $51.8 \%$. That mean in the Gambia, youth engagement in agriculture cannot deter migration, the studied confirmed. Total aids are statistically positive effects on migration. The positive effect is very small, the study asserted.

Do personal remittances received affect net migration, aids, development intervention and economic growth?

Remittance, migration, total aids and economic growth are all interlinks either direct or indirect. From the results confirmed that migration has significant and slightly negative impact on remittance in the Gambia. These small negative effects may be due to the fact that many developing countries particularly the Gambia's are also large recipients of international migrants, they face challenges of integration of immigrants, job competition between migrant and native workers, and fiscal costs associated with provision of social services to the migrants. Total aids, employment in 
agriculture and economic growth has positive significant impacts on remittance in the Gambia the study confirmed. From the existing literatures, Migration and remittances have both direct and indirect effects on the welfare of the population in the migrant sending countries. A cross-country study of 71 developing countries found that a 10\% increase in per capita, official international remittances will lead to 3.5 percent decline in the share of people living in poverty (Adams \& Page, 2005). Evidence from Latin America, Africa, South Asia and other regions suggests that remittances reduce the depth and severity of poverty, as well as indirectly stimulate economic activity (Adams 1991). The dramatic increase in remittances was responsible for one third to one half of the overall reduction in headcount poverty rate in Nepal from 42 percent in 1995-96 to 31 percent in 2003-04 (World Bank 2006a).

iv) Does economic growth affect net migration, personal remittances received, aids and development intervention?

Migration is a choice that influences the welfare of the household, the home community, and in the end the whole economy in various ways (Azam \& Gubert, 2006). The welfare implications of migration on the origin country are most often, though not always, sizable and positive. The economic impact of migration has been intensively studied but is still often driven by ill-informed insights, which, in turn, can lead to public resentment towards migration. These negative opinions risk efforts to adapt migration policies to the new economic and demographic challenges facing many countries (OECD, 2014). There is empirical evidence that remittances contribute to economic growth, through their positive impact on consumption, savings, and investment in macroeconomic. Remittances can also have negative impact on growth in recipient countries by reducing incentives to work, and therefore reducing labor supply. From table 17 below, in the Gambia remittance, migration and total aids have positive significant impacts on economic growth. Increases $10 \%$ of remittance, increase economic growth by $0.14 \%$.Only employment in agriculture has negative impacts on economic growth. $10 \%$ increases in employment in agriculture, decrease economic growth by $0.04 \%$. The economy of the Gambia should deal more on export thereby improve agricultural development. For foreign aid can have both negatively and positively contributes to economic growth depending on the utilization of the funds.

\section{Econometric tests}

\section{Heteroskedasticity tests: White test.}

The hypothesis test is as follows: H0: if errors of the model are homoskedasticity (the errors have the same variance) and Ha: if errors of the model are heteroskedasticity (the errors have different variances) We have 2 options for White Test by using EView.

\section{Option 1: No cross terms}

The White statistic (Obs*R-squared) of 15.9155 has a p-value of 0.0031 . The errors of the model are heteroskedasticity at the 0.05 level because $p=0.0031<0.05$. The White test is a Lagrange multiplier (LM) test. The Lagrange multiplier statistic is $n R^{2}$ where $n$ is the number of observations or sample size.

\section{Option 2: Cross terms}

The White statistic (Obs*R-squared) of 19.32794 has a p-value of 0.0363 . The errors of the model are heteroskedastic at the 0.05 level because $p=0.0363<0.05$.

\section{Breusch-Godfrey $L M$ test for correlation of errors}

The Breusch-Godfrey (BG) test helps to detect an autocorrelation of errors of order greater or equal to one. The hypothesis test is as follows:

H0: the errors of the model are not correlated and Ha: the errors of the model are correlated The Breusch-Godfrey test is a Lagrange multiplier (LM) test. We test an autocorrelation of order 1. After having estimated the parameters by the least ordinary squares method

The Breusch-Godfrey statistic (Obs*R-squared) of 49.70905 has a p-value of 0.0000 . The residuals of the model are correlated of order 1 at the 0.05 level because $p=0.0000<0.05$.

\section{Stability tests}

Chow breakpoint test: The hypothesis test is as follows:

$\mathrm{HO}$ : the model is stable and Ha : the model is unstable We are going to choose two breakpoint dates: 1981 and 1994.1994 is the date of the coup in the Gambia and the new government takes over and we also selected 1981 because was another very dangerous coup that lots of life were lost and businesses were collapsed. 
Breakpoint of 1981

The Chow statistic (F-statistic) of 36.567 has a p-value of 0.0000 . The model is unstable at the 0.05 level because $p=0.0000<0.05$.

Breakpoint of 1994(coup in the Gambia lead to second republic)

The Chow statistic (F-statistic) of 2.8177 has a p-value of 0.034 . The model is unstable at the 0.05 level because $p=0.0034<0.05$. We have a change of regime between the two periods and in that the breakpoint in both period were unstable.

Stability tests:

Cusum tests of Brown, Durbin and Evans. The hypothesis test is as follows:

$\mathrm{HO}$ : the model is stable Ha : the model is unstable.

The cusum tests are graphical.

The rule of decision

The model is stable if the curve does not cross the corridor and the model is unstable if the crosses the corridor.

We have 2 options for Cusum tests. Option 1: Cusum test (CUSUM): This test helps to detect structural instabilities. After having estimated the parameters by the least ordinary square method

The CUSUM does not cross the upper and lower 5\% line, the model is structurally stable.it cross around upper and lower 7\%.

Option 2: Cusum of Squared Test (CUSUMSQ): This test helps to detect punctual instabilities

The CUSUM does not cross the upper and lower 5\% line, the model is structurally stable. The graph shows that 1995 corresponds to a quasi, one-time instability. This instability can be explained by the turmoil that occurred during the 1994 coup by Yaya Jammeh and that was turning point of democracy in the Gambia and many lives were lost during the 22 periods of military roles.

\section{Simulation of the model}

The curves of actual and fitted series are stationary as fitted series fluctuated around the actual. The forecast errors are additive. The simulation is not bad. A model is likely to have a high predictive power because it reproduces accurately the past.

\section{Summary and conclusion}

When we used multiple regression analysis, the results confirmed that migration and remittances have significant positive impact on employment in agriculture in the Gambia. The impacts is larger for remittances than migration itself.10\% increase in remittance, increases the employment in agriculture by approximately $0.29 \%$ if others variables remained constant. Bilateral aids is fairly positive significant impacts on employment in agriculture, while economic growth have significant negative impact on employment in agriculture. This is confirmed in the study done by Clemens, 2018 disbelief about the ability of development aid to effect large variations in youth employment. There is empirical evidence that remittances contribute to economic growth, through their positive impact on consumption, savings, and investment in macroeconomic. Remittances can also have negative impact on growth in recipient countries by reducing incentives to work, and therefore reducing labor supply. From table 17 below, in the Gambia remittance, migration and total aids have positive significant impacts on economic growth. Increases $10 \%$ of remittance, increase economic growth by $0.14 \%$. Only employment in agriculture has negative impacts on economic growth.10\% increases in employment in agriculture, decrease economic growth by $0.04 \%$.The economy of the Gambia should deal more on better utilizations of aids thereby improve agricultural development. 


\section{Acknowledgements}

Not applicable.

\section{Funding}

Not applicable.

\section{Availability of data}

Dataset analyzed in this study is available from the author on reasonable request.

\section{Conflict of Interest}

The author declares that he has no conflict of interest.

\section{Appendix A. Supplementary material}

Supplementary data associated with this article can be found, in the online version, at https://doi.org/10.14254/jems.2020.5-1.5

\section{Citation information}

Ceesay, E. K. (2020). Employment in agriculture, migration, bilateral aids, economic growth and remittance: Evidence from the Gambia. Economics, Management and Sustainability, 5(1), 48-67. doi:10.14254/jems.2020.5-1.5.

\section{References}

Adam, C. S., \& O'Connell, S. A. (1999). Aid, taxation, and development: Analytical perspectives on aid effectiveness in Sub-Saharan Africa. The World Bank. https://doi.org/10.1111/14680343.00060

Adams Jr, R. H. (1998). Remittances, investment, and rural asset accumulation in Pakistan. Economic Development and Cultural Change, 47(1), 155-173. https://doi.org/10.1086/452390

Adams Jr, R. H., \& Page, J. (2005). Do international migration and remittances reduce poverty in developing countries?. World development, 33(10), 1645-1669. https://doi.org/10.1016/j.worlddev.2005.05.004

Adams, R. H. (1991). The effects of international remittances on poverty, inequality, and development in rural Egypt (Vol. 86). Intl Food Policy Res Inst.

Alfaro, L., Chanda, A., Kalemli-Ozcan, S., \& Sayek, S. (2004). FDI and economic growth: the role of local financial markets. Journal of International Economics, 64(1), 89-112. https://doi.org/10.1016/S0022-1996(03)00081-3

Amakom, U., \& Iheoma, C. G. (2014). Impact of migrant remittances on health and education outcomes in sub-Saharan Africa. IOSR Journal of Humanities and Social Science, 19(8), 33-44. https://doi.org/10.9790/0837-19813344

Amega, K. (2018). Remittances, education and health in Sub-Saharan Africa. Cogent Economics \& Finance, 6(1), 1516488. https://doi.org/10.1080/23322039.2018.1516488

Asteriou, D. (2009). Foreign aid and economic growth: New evidence from a panel data approach for five South Asian countries. Journal of Policy Modeling, 31(1), 155-161. https://doi.org/10.1016/j.jpolmod.2008.04.012

Azam, J. P., \& Gubert, F. (2006). Migrants' remittances and the household in Africa: a review of evidence. Journal of African Economies, 15(suppl_2), 426-462. https://doi.org/10.1093/jae/ej1030

Berthélemy, J. C., Beuran, M., \& Maurel, M. (2009). Aid and migration: Substitutes or complements?. World Development, 37(10), 1589-1599. https://doi.org/10.1016/j.worlddev.2009.02.002 
Boubtane, E., Coulibaly, D., \& Rault, C. (2013). Immigration, growth, and unemployment: Panel VAR evidence from OECD countries. Labour, 27(4), 399-420. https://doi.org/10.1111/labr.12017

Burnside, C., \& Dollar, D. (2000). Aid, policies, and growth. American economic review, 90(4), 847868. https://doi.org/10.1257/aer.90.4.847

Butschek, S., \& Walter, T. (2014). What active labour market programmes work for immigrants in Europe? A meta-analysis of the evaluation literature. IZA Journal of Migration, 3(1), 48. https://doi.org/10.1186/s40176-014-0023-6

Carden, A. (2010). Can't buy me growth: On foreign aid and economic change. Journal of Private Enterprise, 25(1), 105-123.

Ceesay, E. K. (2013). Inequality and growth: The Effects of Gender Inequality in Education (Human capita proxy), Employment (labor market participation Proxy) and its impacts on Economic Growth. Munich Personal RePEc Archive.

Ceesay, E. K., Belford, C., Fanneh, M. M., \& Drammeh, H. (2019). Relationship between export, imports and economic growth: an export-led growth strategy for the Gambia using the granger causality test. International Journal of Social Sciences Perspectives, 4(2), 38-47. https://doi.org/10.33094/7.2017.2019.42.38.47

Ceesay, E. K., Sanneh, T., Jawo, A., Jarju, M., \& Jassey, O. (2019). Impact of Personal Remittances Received on Economic Growth in the Gambia. Asian Basic and Applied Research Journal, 1(2), 45-58. Retrieved from http://globalpresshub.com/index.php/ABAARJ/article/view/765

Clemens, M. A., \& Postel, H. M. (2017). Deterring emigration with foreign aid: an overview of evidence from low-income countries (No. 136). IZA Policy Paper. https://doi.org/10.1111/padr.12184

Collier, P., \& Hoeffler, A. (2004). Greed and grievance in civil war. Oxford economic papers, 56(4), 563595. https://doi.org/10.1093/oep/gpf064

Constantin, C. (2006). Sisteme informatice de marketing. Analiza şi prelucrarea datelor de marketing. Aplicaţii în SPSS, Infomarket Publishing House, Brasov.

De, P. K., \& Ratha, D. (2012). Impact of remittances on household income, asset and human capital: Evidence from Sri Lanka. Migration and Development, 1(1), 163-179. https://doi.org/10.1080/21632324.2012.719348

Easterly, W., Levine, R., \& Roodman, D. (2004). Aid, policies, and growth: comment. American economic review, 94(3), 774-780. https://doi.org/10.1257/0002828041464560

Galiani, S., Knack, S., Xu, L. C., \& Zou, B. (2017). The effect of aid on growth: evidence from a Quasiexperiment. Journal of Economic Growth. https://doi.org/10.1007/s10887-016-9137-4

Gamso, J., \& Yuldashev, F. (2018). Does rural development aid reduce international migration?. World Development, 110, 268-282. https://doi.org/10.1016/j.worlddev.2018.05.035

Gibson, J., McKenzie, D., \& Rohorua, H. (2014). Development impacts of seasonal and temporary migration: a review of evidence from the Pacific and Southeast Asia. Asia \& the Pacific Policy Studies, 1(1), 18-32. https://doi.org/10.1002/app5.12

Gyimah-Brempong, K., \& Asiedu, E. (2009, November). Remittances and poverty in Ghana. In 4th African Economic Conference, Addis Ababa, Ethiopia.

Hagen-Zanker, J., \& Himmelstine, C. L. (2013). What do we knowabout the impact of social protection programmes on the decision to migrate?. Migration and Development, 2(1), 117-131

Hansen, H., \& Tarp, F. (2001). Aid and growth regressions. Journal of development Economics, 64(2), 547-570. https://doi.org/10.1016/S0304-3878(00)00150-4

Index-mundi. (2018). Ghana Demographics Profile.

Karras, G. (2006). Foreign aid and long-run economic growth: empirical evidence for a panel of developing countries. Journal of International Development: The Journal of the Development Studies Association, 18(1), 15-28. https://doi.org/10.1002/jid.1187

Kaya, O., Kaya, I., \& Gunter, L. (2012). Development aid to agriculture and economic growth. Review of Development Economics, 16(2), 230-242. https://doi.org/10.1111/j.14679361.2012.00658.x 
Kaya, O., Kaya, I., \& Gunter, L. (2013). Foreign aid and the quest for poverty reduction: Is aid to agriculture effective?. Journal of Agricultural Economics, 64(3), 583-596. https://doi.org/10.1111/1477-9552.12023

Lanati, M., \& Thiele, R. (2018). The impact of foreign aid on migration revisited. World development, 111, 59-74. https://doi.org/10.1016/j.worlddev.2018.06.021

Lokshin, M., Bontch-Osmolovski, M., \& Glinskaya, E. (2010). Work-related migration and poverty reduction in Nepal. Review of Development Economics, 14(2), 323-332. https://doi.org/10.1111/j.1467-9361.2010.00555.x

Lu, Y., \& Treiman, D. J. (2011). Migration, remittances and educational stratification among blacks in apartheid and post-apartheid South Africa. Social Forces, 89(4), 1119-1143. https://doi.org/10.1093/sf/89.4.1119

McKenzie, D., \& Yang, D. (2015). Evidence on policies to increase the development impacts of international migration. The World Bank Research Observer,30(2), 155-192. https://doi.org/10.1093/wbro/lkv001

Minoiu, C., \& Reddy, S. G. (2010). Development aid and economic growth: A positive long-run relation. The Quarterly Review of Economics and Finance, 50(1), 27-39.

OECD. (2014). Is migration good for the economy?. Migration Policy Debates.

Perez-Saiz, H., Dridi, M. J., Gursoy, T., \& Bari, M. (2019). The impact of remittances on economic activity: the importance of sectoral linkages. International Monetary Fund. https://doi.org/10.5089/9781498324489.001 


\section{Appendix}

Net Migration and Peronal remittance

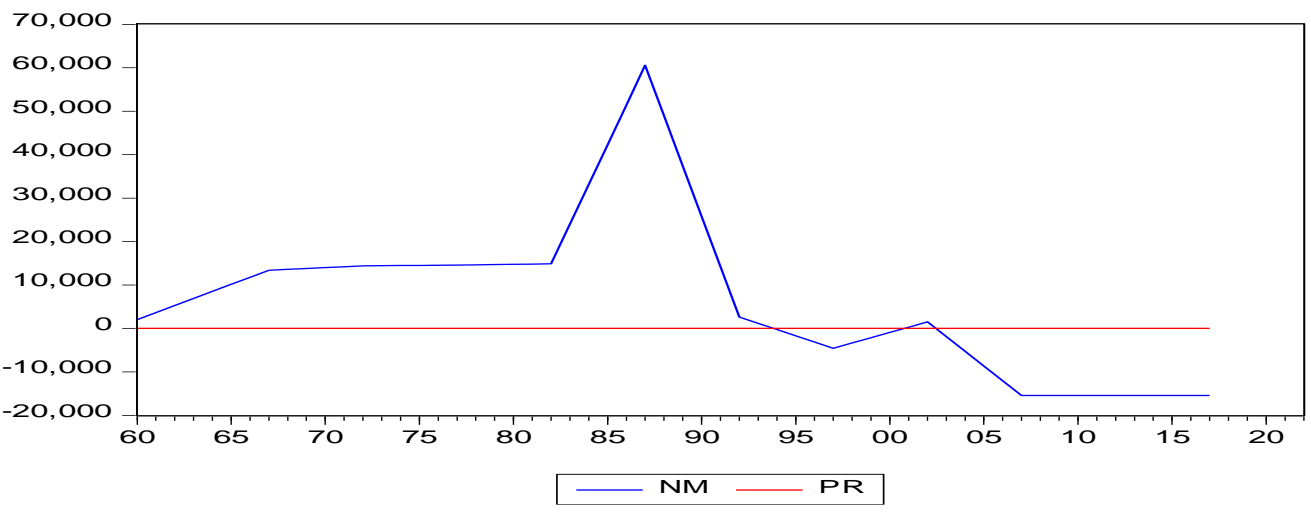

\section{Table: Percentage of remittance inflows to GDP for Gambia}

\begin{tabular}{lc}
\hline DATE & Percentage of Gambians' remittance of GDP \\
\hline $1 / 1 / 2006$ & 9.74 \\
$1 / 1 / 2007$ & 6.97 \\
$1 / 1 / 2008$ & 6.97 \\
$1 / 1 / 2009$ & 8.86 \\
\hline
\end{tabular}

Sources: Retrieved from FRED Economic data, World Bank October 2019
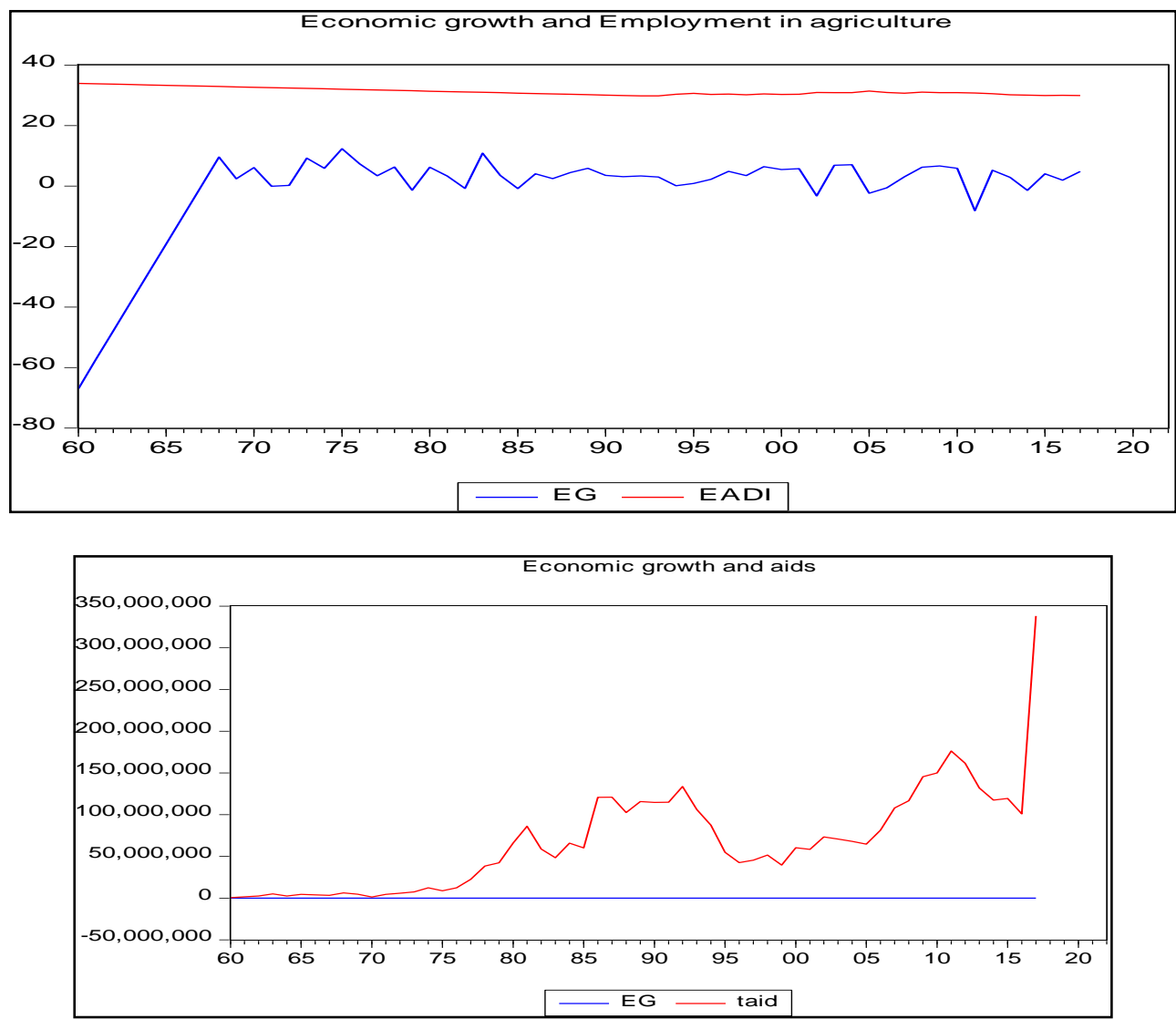
CUSUM TEST

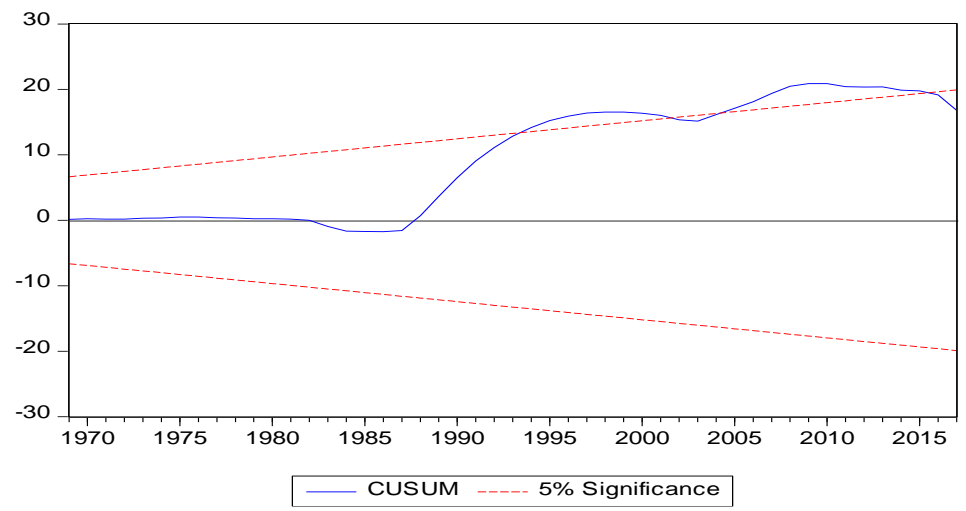

CUSUM SQU.



Residual test

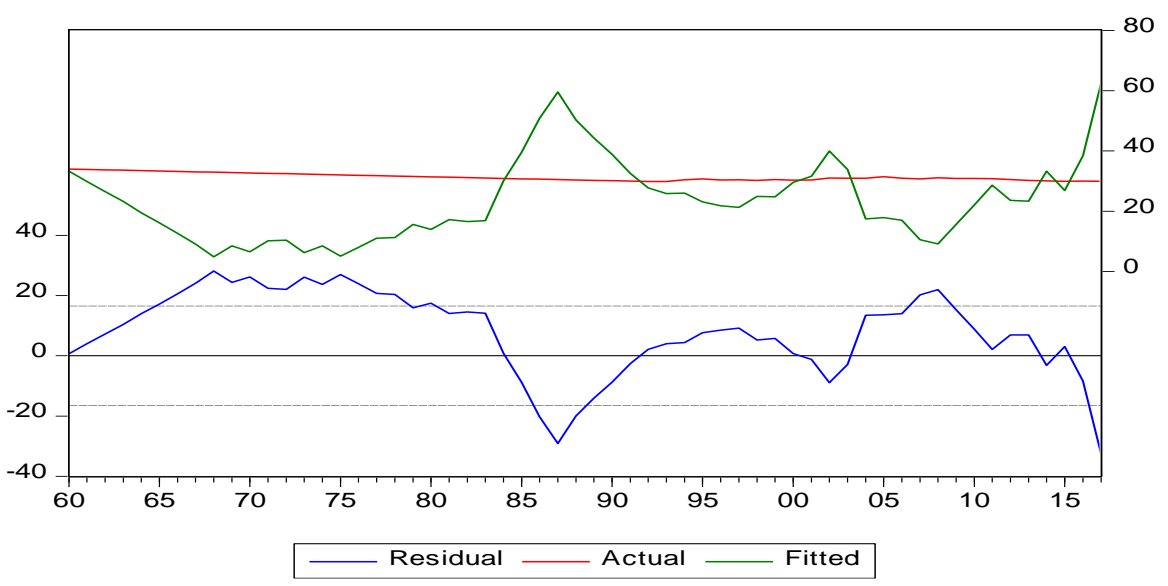

Table 1: Data Sources

Name of Variable

GDP growth (annual \%)

Net migration

Net bilateral aid flows from DAC

donors, United States

Net bilateral aid flows from DAC

donors, European Union

institutions

Net official development

assistance and official aid received

Employment in agriculture (\% of total employment)

taid
Source

WDI

WDI

WDI

WDI

WDI

WDI

WDI
Comment

Current GDP growth\$

Net migration

Net bilateral aid flows from DAC donors, United States \$

Net bilateral aid flows from DAC donors, European Union institutions\$

Net official development assistance and official aid received\$

Employment in agriculture (\% of total employment) e Current Total aid\$

Source: World Development Indicator (WDI). 


\section{Descriptive Statistics}

\begin{tabular}{lccccc}
\multicolumn{7}{l}{ Table 2: Descriptive Statistics } \\
\hline & TAID & EADI & PR & EG & NM \\
\hline Mean & 68431034 & 31.32157 & 3.967717 & -1.477321 & 7035.076 \\
Median & 60330000 & 30.917 & 3.291132 & 3.350291 & 6094.1 \\
Maximum & $3.38 E+08$ & 33.979 & 15.162 & 12.39343 & 60597 \\
Minimum & 540000 & 29.847 & -0.463156 & -67.033 & -15436 \\
Std. Dev. & 61366198 & 1.191712 & 4.281011 & 15.70937 & 17883.04 \\
Skewness & 1.518152 & 0.772382 & 0.672582 & -2.816899 & 0.860811 \\
Kurtosis & 7.502661 & 2.390868 & 2.437259 & 10.42802 & 3.742544 \\
Jarque-Bera & 71.27498 & 6.663568 & 5.138177 & 210.0451 & 8.495437 \\
Probability & 0.0000 & 0.035729 & 0.076605 & 0.0000 & 0.014297 \\
Sum & $3.97 \mathrm{E}+09$ & 1816.651 & 230.1276 & -85.68459 & 408034.4 \\
Sum Sq. Dev. & $2.15 \mathrm{E}+17$ & 80.95015 & 1044.642 & 14066.71 & $1.82 \mathrm{E}+10$ \\
Observations & 58 & 58 & 58 & 58 & 58 \\
\hline
\end{tabular}

Sources: Author's own computation by retrieved data from World Bank Using EViews

\begin{tabular}{|c|c|c|c|c|c|}
\hline $\begin{array}{l}\text { Covariance Analysis: Ordinary } \\
\text { Sample: } 19602017 \\
\text { Included observations: } 58 \\
\text { Correlation } \\
\text { Probability }\end{array}$ & EADI & EG & NM & PR & TAID \\
\hline EADI & 1.0000 & & & & \\
\hline EG & $\begin{array}{c}-0.6360 \\
0.0000\end{array}$ & $\begin{array}{c}1.0000 \\
-----\end{array}$ & & & \\
\hline NM & $\begin{array}{c}0.141189 \\
0.2904\end{array}$ & $\begin{array}{c}0.057438 \\
0.6685\end{array}$ & $\begin{array}{c}1.0000 \\
----\end{array}$ & & \\
\hline PR & $\begin{array}{c}-0.7266 \\
0.0000\end{array}$ & $\begin{array}{l}0.2994 \\
0.0224\end{array}$ & $\begin{array}{c}-0.589 \\
0.000\end{array}$ & $\begin{array}{c}1.0000 \\
----\end{array}$ & \\
\hline TAID & $\begin{array}{c}-0.7188 \\
0.0000\end{array}$ & $\begin{array}{l}0.3206 \\
0.0141\end{array}$ & $\begin{array}{c}-0.266 \\
0.042\end{array}$ & $\begin{array}{l}0.6579 \\
0.0000\end{array}$ & $\begin{array}{c}1.000 \\
----\end{array}$ \\
\hline
\end{tabular}

Sources: Author's own computation by retrieved data from World Bank Using EViews

\begin{tabular}{lccccc}
\multicolumn{7}{l}{ Table 4: Distribution characteristics of the series } \\
& EADI & EG & PR & NM & TAID \\
\hline Mean & 31.32157 & -1.477321 & 3.967717 & 7035.076 & 68431034 \\
Median & 30.917 & 3.350291 & 3.291132 & 6094.1 & 60330000 \\
Maximum & 33.979 & 12.39343 & 15.162 & 60597 & $3.38 E+08$ \\
Minimum & 29.847 & -67.033 & -0.463156 & -15436 & 540000 \\
Std. Dev. & 1.191712 & 15.70937 & 4.281011 & 17883.04 & 61366198 \\
Skewness & 0.772382 & -2.816899 & 0.672582 & 0.860811 & 1.518152 \\
Kurtosis & 2.390868 & 10.42802 & 2.437259 & 3.742544 & 7.502661 \\
Jarque-Bera & 6.663568 & 210.0451 & 5.138177 & 8.495437 & 71.27498 \\
Probability & 0.035729 & 0.0000 & 0.076605 & 0.014297 & 0.0000 \\
Observation & 58 & 58 & 58 & 58 & 58 \\
\hline
\end{tabular}

Sources: Author's own computation by retrieved data from World Bank Using EView

\section{Table 5: Estimation of total Bilateral aid Received model}

Dependent Variable: TAID

Method: Least Squares

Sample (adjusted): 19602017

Included observan: 58 after adjustments

Variable

C

NM

\begin{tabular}{cccc} 
Coefficient & Std. Error & t-Statistic & Prob. \\
7487620 & 8428631 & 8.883555 & 0.0000 \\
-916.148 & 441.9129 & -2.073142 & 0.0428 \\
\hline
\end{tabular}

Sources: Author's own computation by retrieved data from World Bank Using EView 
Table 6: Estimation of net migration model

Dependent Variable: NM

Method: Least Squares

Sample (adjusted): 19602017

Included observati: 58 after adjustments

Variable

\begin{tabular}{cccc} 
Coefficient & Std. Error & t-Statist & Prob. \\
16680.42 & 2637.394 & 6.32458 & 0.0000 \\
-2430.95 & 453.9556 & -5.3550 & 0.0000 \\
\hline
\end{tabular}

$-2430.95$

453.9556

$-5.3550$

0.0000

Sources: Author's own computation by retrieved data from World Bank Using EViews

Table 7: Estimation of economic growth model
\begin{tabular}{lllll} 
Dependent Variable: EG & & & \\
\hline Method: Least Squares & & & & \\
Sample (adjusted): 19602017 & & & & \\
Included observation: 58 after adjustments & & & & \\
Variable & Coefficient & Std. Error & t-Statistic & Prob. \\
C & -5.8379 & 2.718147 & -2.147751 & 0.0361 \\
PR & 1.09901 & 0.467855 & 2.349052 & 0.0224 \\
\hline
\end{tabular}

Sources: Author's own computation by retrieved data from World Bank Using EViews

Table 8: Estimation of economic growth model

Dependent Variable: EG

Method: Least Squares

Sample (adjusted): 19602017

Included observation: 58 after adjustments

Variable

C

Coefficient

Std. Error

t-Statistic

Prob.

NM

$-1.832286$

2.235251

$-0.81972 \quad 0.4158$

Sources: Author's own computation by retrieved data from World Bank Using EViews

Table 9: Estimation of Economic Growth model

Dependent Variable: EG

Method: Least Squares

Date: 02/29/20 Time: 05:26

Sample (adjusted): 19602017

Included observations: 58 after adjustments

Variable

Coefficient

Std. Error

t-Statis

Prob.

$\mathrm{C}$

$-7.09357$

2.966891

$-2.3909$

0.0202

TAID

8.21E-08

3.24E-08

2.5328

0.0141

Sources: Author's own computation by retrieved data from World Bank Using EViews

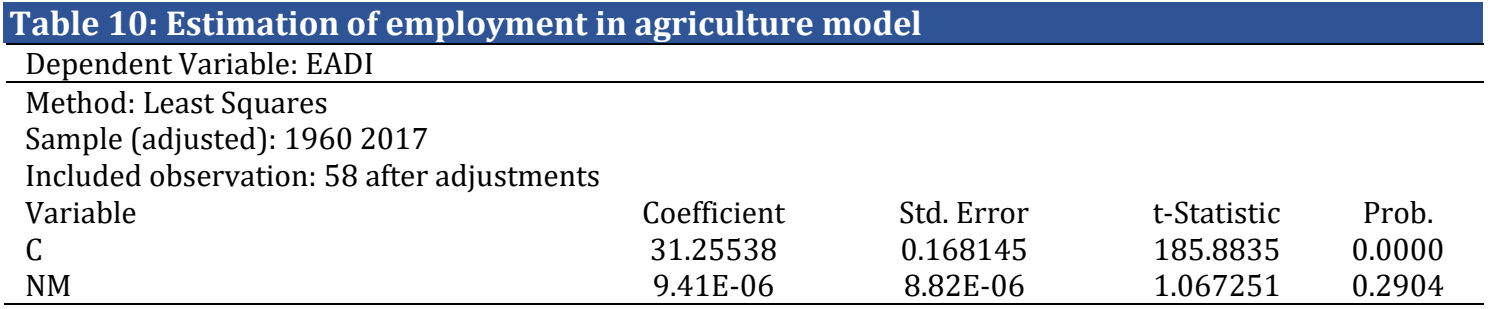

Sources: Author's own computation by retrieved data from World Bank Using EViews

Table 11. Estimation of Total Bilateral aid received model

Dependent Variable: TAID

Method: Least Squares

Sample (adjusted): 19602017

Included observation: 58 after adjustments

Variable

C

Coefficient

$1.23 \mathrm{E}+09$

EADI

$-3701600$

Std. Error
$1.50 \mathrm{E}+08$
4783643

t-Statist

Prob.

Sources: Author's own computation by retrieved data from World Bank Using EViews 
Table 12: Estimation of employment in agriculture

Dependent Variable: EADI

Method: Least Squares

Date: 03/02/20 Time: 02:41

Sample (adjusted): 19602017

Included observation: 58 after adjustments

Variable

Coefficient

Std. Error

t-Statist

Prob.

NM

0.000696

0.000126

5.52247

$9.52 \mathrm{E}-08$

$4.60 \mathrm{E}-08$

2.06734

0.000

TAID

$-0.49446$

PR

2.865932

0.140311

$-3.5240$

0.0435

0.730651

3.92243

0.0009

Sources: Author's own computation by retrieved data from World Bank Using EViews

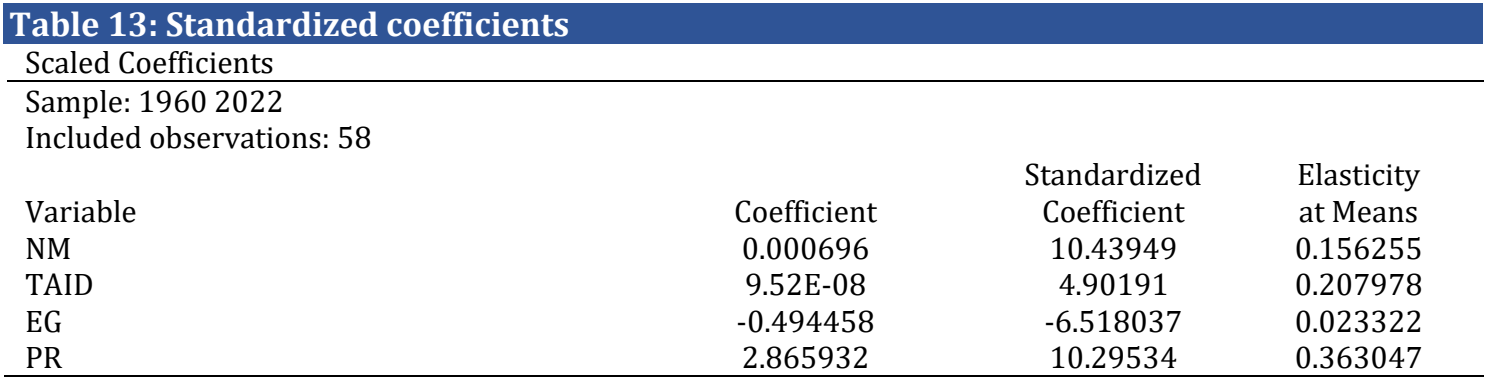

Sources: Author's own computation by retrieved data from World Bank Using EViews

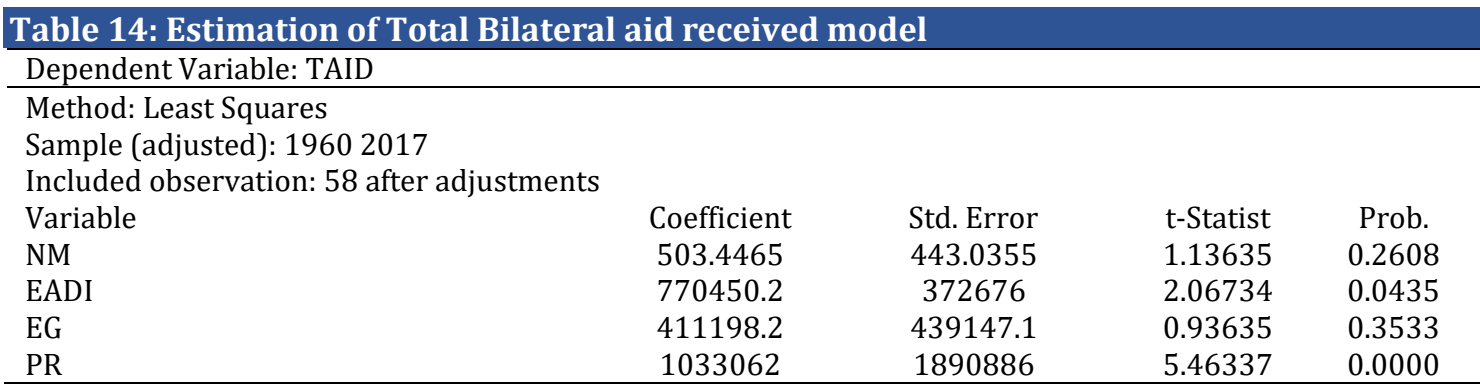

Sources: Author's own computation by retrieved data from World Bank Using EViews

Table 15: Estimation of net migration model
\begin{tabular}{lllll}
\multicolumn{2}{l}{ Dependent Variable: NM } \\
\hline Method: Least Squares \\
Sample (adjusted): 19602017 & & & & \\
Included observation: 58 after adjustments & & & & \\
Variable & Coefficient & Std. Error & t-Statist & Prob. \\
TAID & $4.64 \mathrm{E}-05$ & $4.08 \mathrm{E}-05$ & 1.13635 & 0.2608 \\
EADI & 518.8153 & 93.94619 & 5.52247 & 0.0000 \\
EG & 280.1397 & 128.861 & 2.17396 & 0.0341 \\
PR & -3043.87 & 583.0826 & -5.2203 & 0.0000 \\
\hline
\end{tabular}

Sources: Author's own computation by retrieved data from World Bank Using EViews

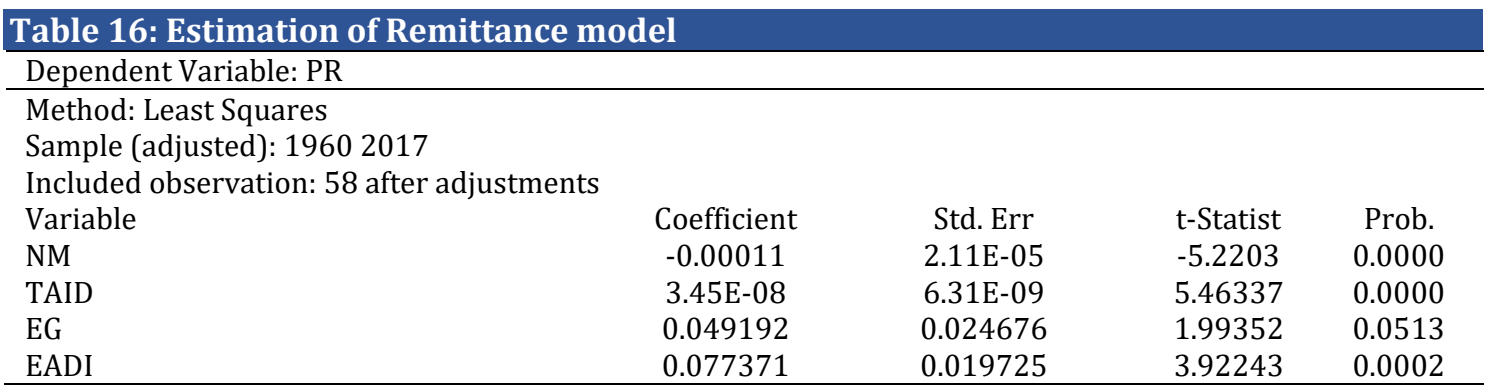

Sources: Author's own computation by retrieved data from World Bank Using EViews 
Table 17: Estimation of economic growth model

Dependent Variable: EG

Method: Least Squares

Date: 03/02/20 Time: 02:45

Sample (adjusted): 19602017

Included observation: 58 after adjustments

Variable

PR

Coefficient

Std. Error

t-Statist

Prob.

NM

1.39352

0.699023

1.9932

0.0513

TAID

3.89E-08

0.000132

2.1739

0.0341

EADI

$-0.37815$

4.15E-08

0.9363

0.3533

Sources: Author's own computation by retrieved data from World Bank Using EViews

\section{After having estimated the parameters by the OLS}

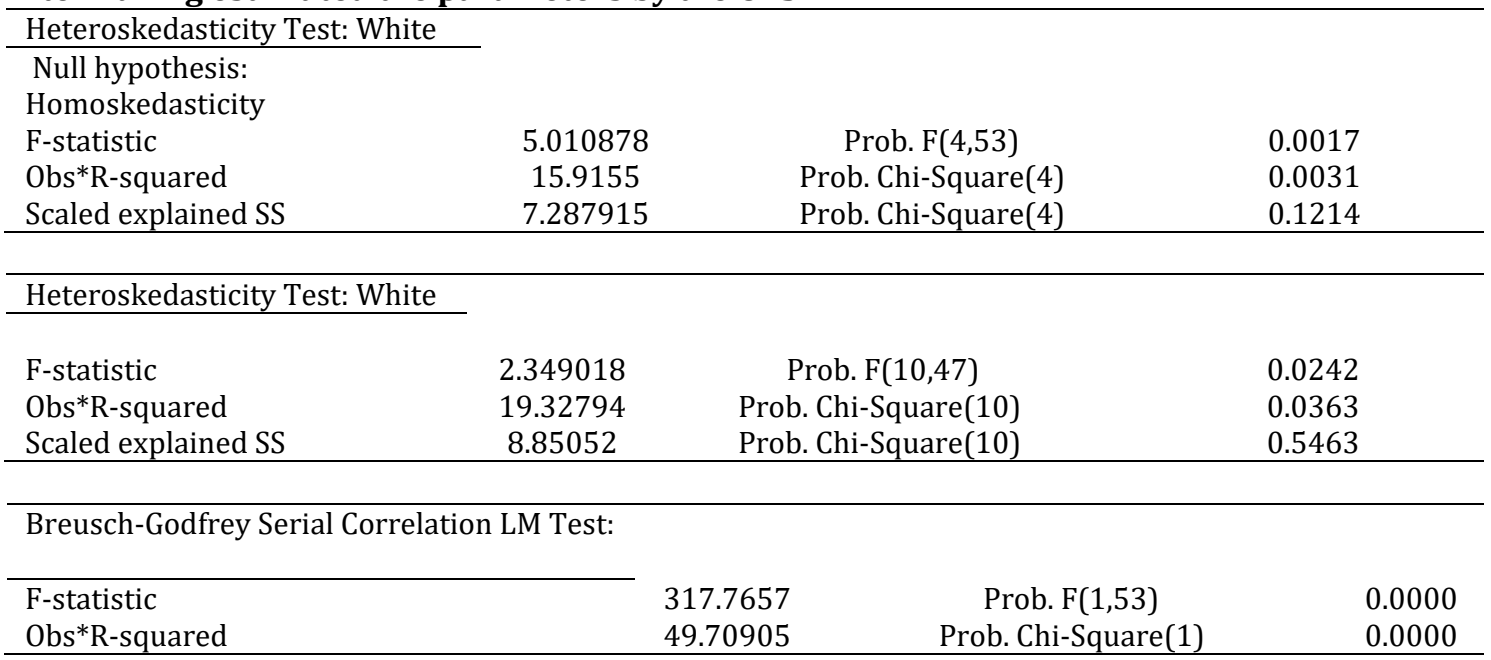

\section{After having estimated the parameters by the least ordinary squares method}

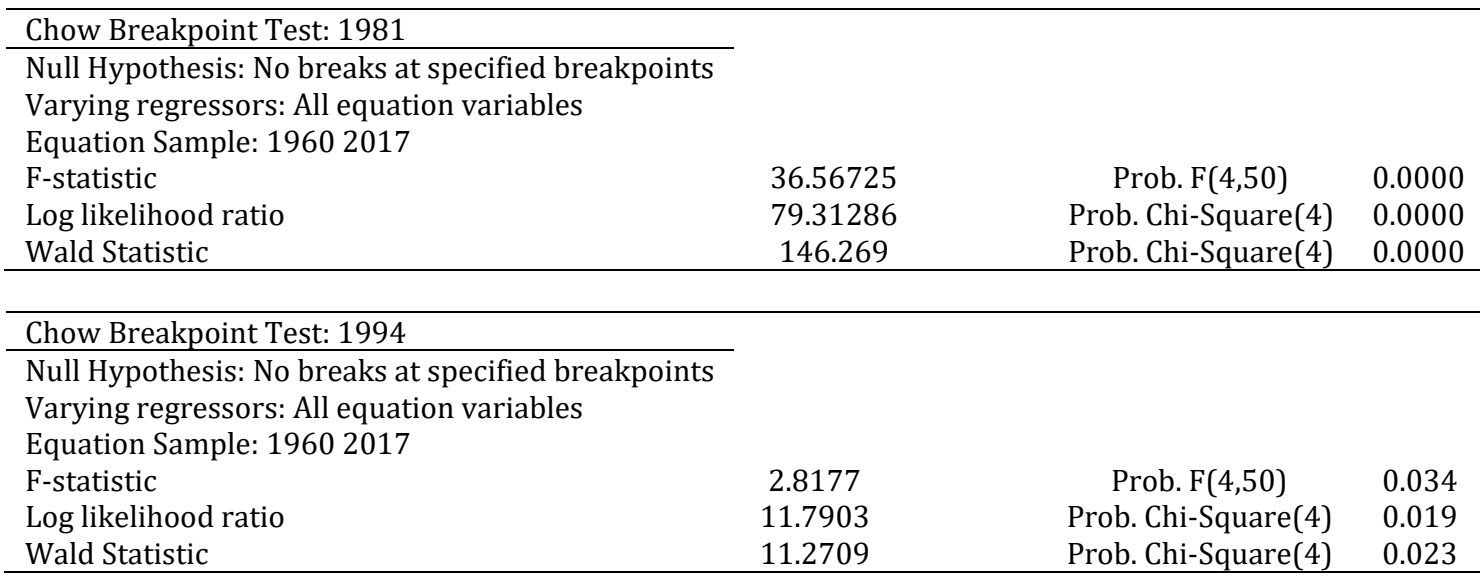

\section{Author's Own Evaluation}

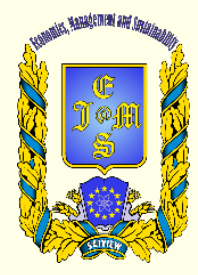

() 2016-2020, Economics, Management and Sustainability. All rights reserved.

This open access article is distributed under a Creative Commons Attribution (CC-BY) 4.0 license.

Share - copy and redistribute

The licensor cannot revoke these freedoms as long as you follow the license terms.

Under the following terms:

Attribution - You must give appropriate credit, provide a link to the license, and indicate if changes were made.

You may do so in any reasonable manner, but not in any way that suggests the licensor endorses you or your use.

No additional restrictions

You may not apply legal terms or technological measures that legally restrict others from doing anything the license permits.

Economics, Management and Sustainability (ISSN: 2520-6303) is published by Scientific Publishing House "CSR",

Poland, EU and Scientific Publishing House "SciView", Poland

Publishing with JEMS ensures:

- Immediate, universal access to your article on publication

- High visibility and discoverability via the JEMS website

- Rapid publication

- Guaranteed legacy preservation of your article

- Discounts and waivers for authors in developing regions

Submit your manuscript to a JEMS at http://jems.sciview.net or submit.jems@sciview.net

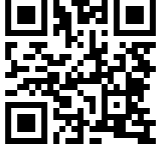

